\title{
EFFECTS OF DIFFERENT OXYGEN CONCENTRATIONS DURING GENERAL ANAESTHESIA FOR ELECTIVE CAESAREAN SECTION*
}

\author{
Gertie F. Marx, M.D., and Cynthia V. Mateo, M.D. $\dagger$
}

IN A PREvIOUS STUDY of mother and infant during caesarean section, ${ }^{1}$ we reported that thiopentone-nitrous oxide-succinylcholine anaesthesia was associated with lower Apgar scores and longer "time to sustained respiration" of the neonate than spinal analgesia, despite comparable acid-base data. Quite unexpectedly, we noted also a very favourable clinical status of several newborn infants after emergency caesarean section for placenta praevia or abruptio placentae coincident with the use of light cyclopropane anaesthesia and postulated this to be related to the high inspired oxygen concentration. Recent studies by Newman $e t a l .^{2}$ and by Althabe and his coworkers ${ }^{3}$ demonstrated a rise in oxygen tensions of foetal scalp capillary blood and foetal tissues when pregnant women breathed increased oxygen concentrations. Quilligan and his associates ${ }^{4}$ showed an elevation in oxygen tension of intervillous space blood and umbilical vein blood in four patients undergoing caesarean section under spinal analgesia during the maternal inhalation of oxygen for five minutes. And Fox and Houle, ${ }^{5}$ in comparing epidural-air and epidural-oxygen analgesia during cacsarean section, found that infants in the latter group had higher oxygen tensions, a lower degrec of metabolic acidosis, and a more rapid onsct of spontaneous respiration. We, therefore, decided to investigate the cffects on foetus and neonate of different oxygen concentrations during general anacsthesia for clective repeat caesarean section.

\section{METHOD}

Sevinty-five healthy term-pregnant women were divided into five sequential groups. Except for the anaesthetic agent and the concentration of inhaled oxygen used for maintenance of anaesthesia, they were managed identically. Left uterine displacement was instituted prophylactically, a continuous infusion of lactated Ringer's solution with 5 per cent dextrose was administered and atropine $0.4 \mathrm{mg}$ injected intravenously. During preoxygenation, the patient's minute volume was measured with a Wright Respirometer incorporated into the circle system. Induction of anaesthesia with $200-250 \mathrm{mg}$ of thiopentone (Pentothal) was followed by injection of $60 \mathrm{mg}$ of succinylcholine (Anectine) and endotracheal intubation. A succinylcholine solution, 0.1 per cent, was infused during maintenance, and respirations were controlled manually with the preanaesthetic minute volume as a guide.

\footnotetext{
'Presented in part at the American Society of Anesthesiologists' Meeting, New York City, October 1970.

fFrom the Department of Anesthesiology of the Albert Einstein College of Medicine and Affiliated Hospitals, Bronx, New York, U.S.A.
} 
Based on known values of relative MAC (minimum alveolar concentration) in normal man, ${ }^{6,7}$ the delivered concentrations of the different anaesthetic agents were calculated to produce comparable levels of light anaesthesia (approximately 2/3 MAC).

Twenty-five patients received what we designated as a low oxygen concentration; 13 of these were given 28 per cent oxygen-6/2 per cent cyclopropane ( $400-425 \mathrm{ml}$ of $\mathrm{C}_{3} \mathrm{H}_{6}$ added to 6 liters of a mixture of 70 per cent nitrogen-30 per cent oxygen) (third group) and 12 were anaesthetized with 33 per cent oxygen-67 per cent nitrous oxide ( $2 \mathrm{~L}: 4 \mathrm{~L}$ ) (first group). Twenty-five women received a medium oxygen concentration consisting of 66 per cent oxygen-33 per cent nitrous oxide ( $4 \mathrm{~L}: 2 \mathrm{~L}$ ) -1 1/4 $^{\prime}$ per cent fluroxene (Fluoromar) (fifth group). And 25 patients were given a high oxygen concentration; 12 of these received 93 per cent oxygen- $6 / 2$ per cent cyclopropane ( $400-425 \mathrm{ml}$ of $\mathrm{C}_{3} \mathrm{H}_{6}$ added to 6 liters of oxygen) (second group) and 13 received 97 per cent oxygen-2 $2 \frac{1}{2}$ per cent fluroxene ( $\mathrm{O}_{2} 6$ liters) (fourth group).

At the time of delivery, blood samples were obtained from the maternal radial artery as well as from the umbilical vein and artery of a cord segment doubly clamped prior to the infant's first breath. A sample of the inspired anaesthetic mixture was also checked for oxygen concentration. The oxygen, carbon dioxide and $\mathrm{pH}$ determinations were made with Radiometer electrodes and read-out system. Base change was calculated from the nomogram of Siggaard-Andersen et al., ${ }^{8}$ and the foetal oxygen saturation from the dissociation curve of Nelson et al. ${ }^{9}$ The clinical condition of the newborn infants was evaluated according to the recommendations of Apgar ${ }^{10}$ and James et al. ${ }^{11}$

The data are expressed as the mean \pm 1 standard error. Student's $t$-test and the coefficient of correlation ${ }^{12}$ were used for the statistical analyses.

\section{Results}

Maternal arterial carbon dioxide tensions were within \pm 3 torr of normal (30-34 torr) in all patients, eliminating the potential effects of hyper- or hypoventilation on the foetus. Maternal blood $\mathrm{pH}$ and base change values were also within close ranges (Table I). Likewise, umbilical vein and artery blood $\mathrm{pH}$ and carbon dioxide

TABLE I

Maternal Arterial Carbon Dioxide Tensions, pH and Base Change Values were Wrthin Close Ranges in all Groups

\begin{tabular}{ccccc}
\hline Anaesthetic & $\begin{array}{c}\text { No. } \\
\text { cases }\end{array}$ & $\begin{array}{c}\mathrm{PacO}_{2} \\
\text { (torr) }\end{array}$ & $\mathrm{pH}$ & $\begin{array}{c}\text { Base deficit } \\
\text { (mEq/l) }\end{array}$ \\
\hline Low $\mathrm{O}_{2}$ concentration & 25 & $31.6 \pm 0.9$ & $7.42 \pm 0.01$ & $3.8 \pm 0.4$ \\
$28 \% \mathrm{O}_{2}-6 \frac{1}{2} \% \mathrm{C}_{3} \mathrm{H}_{6}$ & 13 & $32.4 \pm 1.0$ & $7.41 \pm 0.01$ & $3.8 \pm 0.6$ \\
$33 \% \mathrm{O}_{2}-67 \% \mathrm{~N}_{2} \mathrm{O}$ & 12 & $30.8 \pm 0.8$ & $7.42 \pm 0.02$ & $3.8 \pm 0.6$ \\
Medium $\mathrm{O}_{2}$ concentration & & & & \\
$65 \% \mathrm{O}_{2}-33 \% \mathrm{~N}_{2} \mathrm{O}-1 \frac{1}{4} \% \mathrm{C}_{4} \mathrm{H}_{5} \mathrm{OF}_{3}$ & 25 & $30.2 \pm 0.6$ & $7.42 \pm 0.01$ & $3.6 \pm 0.3$ \\
High $\mathrm{O}_{2}$ concentration & 25 & $32.8 \pm 0.8$ & $7.41 \pm 0.01$ & $3.3 \pm 0.6$ \\
$93 \% \mathrm{O}_{2}-6 \frac{1}{2} \% \mathrm{C}_{3} \mathrm{H}_{6}$ & 12 & $32.3 \pm 0.9$ & $7.42 \pm 0.01$ & $3.0 \pm 0.9$ \\
$\mathbf{9 7 \%} \mathrm{O}_{2}-2 \frac{11}{2} \% \mathrm{C}_{4} \mathrm{H}_{5} \mathrm{OF}_{3}$ & 13 & $33.2 \pm 0.8$ & $7.41 \pm 0.02$ & $3.6 \pm 0.6$ \\
\hline
\end{tabular}


TABI,E II

Umbilical Vein (Uy) and Artery (ua) Blood Carbon Dioxide lensions and ph Values Did Not Differ Markedly in the Various Groups

\begin{tabular}{|c|c|c|c|c|}
\hline Anaesthetic & $\begin{array}{l}\text { (uv) } \mathrm{CO}_{2} \\
\text { (iorr) }\end{array}$ & uv pH & $\begin{array}{l}\mathrm{P}\left(\text { ua) } \mathrm{CO}_{4}\right. \\
\text { (torr) }\end{array}$ & UA $p H$ \\
\hline $\begin{array}{l}\text { Low } \mathrm{O}_{2} \text { concentration } \\
28 \% \mathrm{O}_{2}-6 \frac{1}{2} \% \mathrm{C}_{3} \mathrm{H}_{6} \\
33 \% \mathrm{O}_{2}-67 \% \mathrm{~N}_{2} \mathrm{O}\end{array}$ & $\begin{array}{l}39.2 \pm 1.2 \\
30.0 \pm 1.3 \\
39.4 \pm 2.1\end{array}$ & $\begin{array}{l}7.33 \pm 0.01 \\
7.34 \pm 0.02 \\
7.32 \pm 0.02\end{array}$ & $\begin{array}{l}46.8 \pm 1.3 \\
45.8 \pm 1.6 \\
47.9 \pm 2.2\end{array}$ & $\begin{array}{l}7.26 \pm 0.01 \\
7.27 \pm 0.02 \\
7.26 \pm 0.02\end{array}$ \\
\hline $\begin{array}{l}\text { Medium } \mathrm{O}_{2} \text { concentration } \\
\qquad 65 \% \mathrm{O}_{2}-33 \% \mathrm{~N}_{2} \mathrm{O}-1 \frac{1}{4} \% \mathrm{C}_{4} \mathrm{H}_{5} \mathrm{OI}^{2}\end{array}$ & $39.0 \pm 1.0$ & $7.33 \pm 0.02$ & $46.2 \pm 1.2$ & $7.27 \pm 0.01$ \\
\hline $\begin{array}{l}\text { High } \mathrm{O}_{2} \text { concentration } \\
\quad 93 \% \mathrm{O}_{2}-6 \frac{1}{2} \% \mathrm{C}_{3} \mathrm{H}_{6} \\
97 \% \mathrm{O}_{2}-2 \frac{1}{2} \% \mathrm{C}_{4} \mathrm{H}_{5} \mathrm{OF}_{3}\end{array}$ & $\begin{array}{l}40.1 \pm 1.4 \\
38.8 \pm 2.6 \\
41.2 \pm 1.6\end{array}$ & $\begin{array}{l}7.34 \pm 0.01 \\
7.36 \pm 0.02 \\
7.32 \pm 0.02\end{array}$ & $\begin{array}{l}47.2 \pm 1.8 \\
44.0 \pm 3.4 \\
49.8 \pm 1.5\end{array}$ & $\begin{array}{l}7.27 \pm 0.01 \\
7.30 \pm 0.02 \\
7.26 \pm 0.01\end{array}$ \\
\hline
\end{tabular}

TABLE III

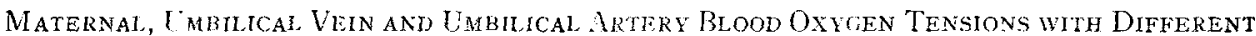
INSPIRLD OXYGEN TENSIONS

\begin{tabular}{|c|c|c|c|c|}
\hline Anaesthetic & $\begin{array}{l}\text { Measured } \\
\text { inspired Po. } \\
\text { (torr) }\end{array}$ & $\begin{array}{c}\mathrm{PaO}_{2} \\
\text { (torr) }\end{array}$ & $\begin{array}{l}\mathrm{P}(\text { uv }) \mathrm{O}_{2} \\
\text { (torr) }\end{array}$ & $\begin{array}{c}\mathrm{P}(\text { ua }) \text { o, } \\
\text { (torr) }\end{array}$ \\
\hline $\begin{array}{l}\text { Low } \mathrm{O}_{2} \text { concentration } \\
28 \% \mathrm{O}_{2}-6 \frac{1}{2} \% \mathrm{C}_{3} \mathrm{H}_{6} \\
33 \% \mathrm{O}_{2}-67 \% \mathrm{~N}_{2} \mathrm{O}\end{array}$ & $\begin{array}{l}230 \pm 4 \\
200 \pm 2 \\
252 \pm 2\end{array}$ & $\begin{array}{r}107.20 \pm 5.21 \\
90.77 \pm 2.72 \\
125.00 \pm 7.70\end{array}$ & $\begin{array}{l}29.72 \pm 1.50 \\
31.00 \pm 6.36 \\
28.33 \pm 2.42\end{array}$ & $\begin{array}{l}18.56 \pm 1.46 \\
19.08 \pm 1.80 \\
18.00 \pm 2.40\end{array}$ \\
\hline $\begin{array}{l}\text { Medium } \mathrm{O}_{2} \text { concentration } \\
\quad 65 \% \mathrm{O}_{2}-33 \% \mathrm{~N}_{2} \mathrm{O}-1 \frac{1}{4} \% \mathrm{C}_{4} \mathrm{H}_{5} \mathrm{OF}_{3}\end{array}$ & $488 \pm 2$ & $282.60 \pm 9.97$ & $34.96 \pm 1.05$ & $23.04 \pm 0.72$ \\
\hline $\begin{array}{l}\text { High } \mathrm{O}_{2} \text { concentration } \\
93 \% \mathrm{O}_{2}-6 \frac{1}{2} \% \mathrm{C}_{3} \mathrm{H}_{6} \\
97 \% \mathrm{O}_{2}-2 \frac{1}{2} \% \mathrm{C}_{4} \mathrm{H}_{5} \mathrm{OF}_{3}\end{array}$ & $\begin{array}{l}718 \pm 4 \\
698 \pm 2 \\
736 \pm 1\end{array}$ & $\begin{array}{l}387.32 \pm 12.29 \\
381.42 \pm 14.82 \\
392.77 \pm 19.76\end{array}$ & $\begin{array}{l}41.20 \pm 1.59 \\
40.17 \pm 2.22 \\
42.15 \pm 8.40\end{array}$ & $\begin{array}{l}25.96 \pm 1.11 \\
26.75 \pm 1.10 \\
25.23 \pm 1.30\end{array}$ \\
\hline
\end{tabular}

Note; The differences between low-, medium-, and high-oxygen groups are statistically significant $(p<0.001$ for maternal values, $p<0.01$ or $<0.05$ for foetal valnes $)$

values did not differ markedly in the various groups (Table II). On the other hand, oxygen tensions in both maternal and foetal bloods were significantly different; they were lowest in the two groups receiving low inspired oxygen, intermediate in the group inhaling the $2 / 3$ oxygen mixture, and highest in the two groups anaesthetized with high inspired oxygen (Table III). The correlation coefficient between maternal and umbilical vein blood oxygen tension was $0.60(p<0.01)$ in the 25 cases of the low-oxygen groups, $0.44(p<0.05)$ in the 25 cases of the medium oxygen group, and 0.30 (not significant) in the 25 cases of the high oxygen groups. The corresponding correlation coefficients between umbilical vein and artery blood oxygen tensions were $0.83(p<0.001), 0.59(p<0.01)$ and $0.43(p<0.05)$. Oxygen saturation and oxygen content of the cord bloods were also significantly different among the high, medium, and low inspired oxygen groups (Table IV).

Although the induction-delivery intervals were similar, the clinical condition of the neonates differed. Mean time to sustained respiration was 57 seconds in the low oxygen groups, 19 seconds in the medium oxygen group and 12 seconds in the high oxygen groups $(p<0.001$ between low and medium or high). Twelve infants in the low oxygen groups scored 7 or less on the one-minute Apgar score as compared to four infants in the medium and two in the high oxygen groups (Table V). 
TABLE IV

Umbilical Vein and Artery Blood Oxygen Saturation and Content

\begin{tabular}{|c|c|c|c|c|}
\hline \multirow{2}{*}{$\begin{array}{c}\text { Inspired } \\
\text { oxygen } \\
\text { concentration }\end{array}$} & \multicolumn{2}{|c|}{$\mathrm{O}_{2}$ saturation $(\%)$} & \multicolumn{2}{|c|}{$\mathrm{O}_{2}$ content $(\mathrm{ml})$} \\
\hline & UV & UA & uv & UA \\
\hline Low & $58.3 \pm 3.8$ & $30.4 \pm 3.1$ & $12.5 \pm 0.8$ & $6.6 \pm 0.7$ \\
\hline Medium & $68.8 \pm 1.7$ & $38.5 \pm 1.8$ & $14.8 \pm 0.4$ & $8.3 \pm 0.4$ \\
\hline High & $77.0 \pm 2.0$ & $46.7 \pm 2.1$ & $16.3 \pm 0.4$ & $9.9 \pm 0.5$ \\
\hline
\end{tabular}

Note: The differences between the groups were statistically significant $(p<0.001$ between low and high oxygen concentration groups, $p<0.01$ or $<0.05$ between (a) low and medium and (b) medium and high groups).

TABLE $\mathrm{V}$

The Clinical Condition of the Newborn Infants IMPROVED WITH INCREASING INSPIRED OXYGEN CONCENTRATION

\begin{tabular}{cccc}
$\begin{array}{c}\text { Inspired } \\
\text { oxygen } \\
\text { concentration }\end{array}$ & $\begin{array}{c}\text { I.D.I. } \\
\text { (min) }\end{array}$ & $\begin{array}{c}\text { T.S.R. } \\
\text { (sec) }\end{array}$ & $\begin{array}{c}\text { No. infants } \\
\text { scoring } \\
7 \text {-or-less }\end{array}$ \\
\hline I.ow & $12.4 \pm 1.0$ & $57.3 \pm 7.9$ & 12 \\
Medium & $12.5 \pm 0.7$ & $18.8 \pm 3.2$ & 4 \\
High & $13.0 \pm 0.7$ & $12.2 \pm 3.1$ & 2 \\
\hline
\end{tabular}

NOTE: The differences in time to sustained respiration are statistically significant between low- as compared to mediumand high-oxygen groups $(p<0.001)$.

TABLE VI

Foetal and Neonatal Results Improved with Increasing Maternal Arterial Oxygen TENSION

\begin{tabular}{|c|c|c|c|c|c|c|c|}
\hline Maternal $\mathrm{PaO}_{2}$ (torr) & $61-100$ & $101-160$ & $181-240$ & $241-300$ & $301-360$ & $361-420$ & $421-520$ \\
\hline No. cases & 13 & 12 & 3 & 10 & 19 & 11 & 7 \\
\hline $\begin{array}{l}\mathrm{P}(\mathrm{uv}) \mathrm{O}_{2} \\
\text { (torr) }\end{array}$ & $\begin{array}{r}28.6 \\
( \pm 1.9)\end{array}$ & $\begin{array}{c}30.9 \\
( \pm 2.3)\end{array}$ & 29.0 & $\begin{array}{c}35.1 \\
( \pm 0.4)\end{array}$ & $\begin{array}{r}38.3 \\
( \pm 1.7)\end{array}$ & $\begin{array}{r}40.5 \\
(+2.7)\end{array}$ & $\begin{array}{r}41.3 \\
(+2.6)\end{array}$ \\
\hline $\mathrm{P}(\mathrm{ua}) \mathrm{O}_{2}$ & 16.1 & 20.3 & 20.7 & 22.5 & 25.1 & 26.1 & $\begin{array}{r} \pm 2.0) \\
25.1\end{array}$ \\
\hline (torr) & $( \pm 1.9)$ & $( \pm 2.1)$ & 323 & $( \pm 1.0)$ & $( \pm 1.0)$ & $( \pm 1.5)$ & $( \pm 1.0)$ \\
\hline $\begin{array}{l}\text { T.S.R. } \\
\text { (sec.) }\end{array}$ & $\begin{array}{c}61.5 \\
( \pm 7.8)\end{array}$ & $\begin{array}{r}54,2 \\
( \pm 14.4)\end{array}$ & 33.3 & $\begin{array}{l}26.7 \\
( \pm 6.7)\end{array}$ & $\begin{array}{l}11.1 \\
( \pm 3.2)\end{array}$ & $\begin{array}{l}12.5 \\
( \pm 4.6)\end{array}$ & $\begin{array}{r}14.3 \\
( \pm 3.7)\end{array}$ \\
\hline $\begin{array}{l}\text { No. infants with score } \\
\text { "7-or-below" }\end{array}$ & 7 & 5 & 2 & 2 & 1 & 1 & 0 \\
\hline "6-or-below" & 4 & 2 & 1 & 0 & 0 & 0 & 0 \\
\hline
\end{tabular}

NOTE: There was no further change as the material oxygen tension rose above 300 torr.

Analysis of the foetal and neonatal data revealed the lowest foetal oxygenations and longest times to sustained respiration when the maternal $\mathrm{PaO}_{2}$ was below 100 torr and the highest foetal oxygenations and shortest times to sustained respiration when the $\mathrm{PaO}_{2}$ was 300 torr or more. However, there was no further foetal or neonatal change as the maternal oxygen tension rose above 300 torr (Table VI).

\section{Discussion}

The results of the study show that the clinical condition of the infant was improved when umbilical cord blood oxygenation had been increased by elevation 
of the maternal arterial oxygen tension. Although three anaesthetic agents were employed and differences in their effect on the foetus cannot be excluded, the similarity of results in the two low as well as the two high-oxygen groups and the difference in results between the two cyclopropane groups point to the inspired oxygen concentration as a critical factor. Optimal conditions were obtained when the maternal $\mathrm{PaO}_{2}$ was 300 torr or higher. This finding is in agreement with similar recent studies. Baraka, ${ }^{13}$ in 15 elective caesarean sections managed under general anaesthesia with different oxygen concentrations, observed that foetal oxygen tension was positively correlated with maternal oxygen tension in the range of 78 to 200-300 torr, but was not further increased with elevation of the maternal oxygen tension to 500 torr. Rorke, Davey and Du Toit, ${ }^{14}$ in a series of 34 elective caesarean sections performed with inhalation anaesthesia, demonstrated a significant correlation between the level of foetal oxygenation and the clinical state of the infant at birth as assessed by the Apgar score. Fourteen of their patients received 65 per cent nitrous oxide- 33 per cent oxygen-2 per cent ether, ten women were given 33 per cent nitrous oxide-65 per cent oxygen-2 per cent ether, and the remaining ten received oxygen with 0.3 per cent methoxyflurane (Penthrane). With increase in maternal $\mathrm{PaO}_{2}$ to approximately 300 torr (eight of the women receiving 65 per cent oxygen), a significant $(p<0.001)$ increase in umbilical vein and artery blood oxygen tensions occurred, but with elevation above 300 torr (women receiving over 99 per cent oxygen), there was a progressive (although statistically not significant) decrease in the foetal oxygen levels. However, a small but significant $(p<0.01)$ increase in maternal arterial carbon dioxide tension was noted with the increase in oxygen tension and was associated with an even greater increase in foetal carbon dioxide levels. These differences in carbon dioxide levels may have been responsible for the slight decrease in foetal oxygenation since a similar decrease was not observed by Newman ${ }^{2}$ or by us, although the mechanism is difficult to explain.

Because of the greater acidity of foetal blood and the slope of the foetal oxygendissociation curve, an increase in foetal oxygen leads to a relatively greater increase in oxygen saturation and content. The greater oxygen content compensates for the decrease in total blood volume or red cell volume associated with abdominal delivery which may result from failure to receive placental blood or from actual loss of blood into the placenta. ${ }^{15}$ An increased oxygen content may also act as a reservoir permitting the neonate to withstand postnatal apnoea or postnatal deprivation of oxygen during suctioning of the airway for longer periods. In a neutral thermal environment, the oxygen-consumption of the human newborn infant is approximately $4.6 \mathrm{ml} / \mathrm{kg} / \mathrm{min} .{ }^{16} \mathrm{~A}$ three-kilogram infant from our high-oxygen group (umbilical artery oxygen content $9.9 \mathrm{ml}$ ) would, thus, have a 43-second supply of oxygen at birth as compared to a 29 -second reserve in a similar infant from the lowoxygen group (umbilical artery oxygen content $6.6 \mathrm{ml}$ ), an increase of 50 per cent.

Since the shunts across the maternal pulmonary circulation and across the placenta ${ }^{14.17}$ are large yet unpredictable, and since we found no deterioration in the foetal or neonatal well-being with increases in maternal oxygen tension, we believe that an inspired oxygen concentration of close to 100 per cent is optimal for caesarean section provided that pain and awareness by the parturient woman ${ }^{18}$ can be avoided. Considering the effects on both the mother and the infant, our best results were obtained with cyclopropane-oxygen. When this agent cannot be used, 
a 33 per cent nitrous oxide- 67 per cent oxygen-mixture potentiated by a halogenated vapour seems to be a rational substitute.

\section{Summary AND CONCluSIONS}

The influence of different oxygen concentrations on foetal oxygenation and neonatal clinical status during general anaesthesia for elective caesarean section was evaluated in 75 term-pregnant women. One-third of the patients received what we designated as a low oxygen concentration ( 28 per cent or 33 per cent), one-third a medium concentration ( 65 per cent), and one-third a high concentration ( 93 per cent or 97 per cent).

Oxygen tensions in both maternal and foetal bloods as well as oxygen saturation and content of foetal bloods increased significantly with increases in the inspired oxygen concentration. Foetal oxygenation was lowest and time to sustained respiration longest when maternal $\mathrm{PaO}_{2}$ was below 100 torr. Foetal oxygenation was highest and time to sustained respiration shortest when maternal $\mathrm{PaO}_{2}$ was 300 torr or more; no further foetal or neonatal change occurred as the maternal oxygen tension rose above 300 torr.

An inspired oxygen concentration of at least 65 per cent is recommended for caesarean section anaesthesia.

\section{RÉSUMÉ}

L'influence de différentes concentrations d'oxygène sur le fœetus et le nouveau né pendant l'anesthésie générale pour césariennes sélectives a été evaluée chez 75 grossesses à terme. Un tiers des patients a reçu ce que nous avons designé comme concentration basse d'oxygène ( 28 pour cent ou 33 pour cent); un tiers a reçu une concentration moyenne ( 65 pour cent) et le dernier tiers une concentration forte ( 93 pour cent ou 97 pour cent).

Les tensions et saturations sanguines d'oxygène chez la mère et chez le foetus ont augmenté proportionellement avec la fraction inspirée d'oxygène. L'oxygénation fœtale fut la plus basse et le temps de respiration soutenue le plus élevé quand la tension maternelle d'oxygène fut au dessous de 100 torr. L'oxygénation foetale fut maximale et le temps de respiration soutenue le plus court quand la tension maternelle d'oxygène fut à ou dessus de 300 torr. Aucun changement fœtal ou néonatal n'a été observé quand la tension d'oxygène maternelle fut au dessus de 300 torr.

Une concentration d'oxygène inspiré d'au moins 65 pour cent est recommendée pour l'anesthésie de la césarienne.

\section{REFERENCES}

1. Marx, G. F.; Cosmi, E. V.; \& Wollman, S. B. Biochemical Status and Clinical Condition of Mother and Infant at Cesarean Section. Anesth. \& Analg., 48: 986 (1969).

2. Newman, W.; McKinnan, L.; Phillips, L.; Paterson, P.; \& Wood, C. Oxygen Transfer from Mother to Fetus during Labor. Am. J. Obst. \& Gynec., 99: 61 (1967).

3. Althabe, O.; Schwarcz, R. L.; Pose, S. V.; Escarcena, L.; \& Caldeyro-Barcia, R. Effects on Fetal Heart Rate and Fetal $\mathrm{Po}_{2}$ of Oxygen Administration to the Mother. Am. J. Obst. \& Gynec., 98: 858 ( 1967 ). 
4. Quilligan, E. J.; Vasicka, A.; Aznar, R.; Lipsitz, P. J; Moore, T.; \& Bloor, B. M. Partial Pressure of Oxygen in Intervillous Space and Umbilical Vessels. Am. J. Obst. \& Gynec., 79: 1048 ( 1960).

5. Fox, G. S., \& Houte, G. L. Acid-Base Studies in Elective Caesarean Sections During Epidural and General Anaesthesia. Canad. Anaesth. Soc. J., 18: 60 (1971).

6. Saidman, L. J.; Eger, E. I.; Munson, E. S.; Babad, A. A.; \& Muallem, M. Minimum Alveolar Concentrations of Methoxyflurane, Halothane, Ether and Cyclopropane in Man: Correlation with Theories of Anesthesia. Anesthesiology, 28: 994 (1967).

7. Miller, R. D.; Wahrenbrock, E. A.; Schroeder, C. F.; Knipstein, T. W.; Eger, E. I.; \& Bueched, D. R. Ethylene-Halothane Anesthesia: Addition or Synergism? Anesthesiology, 31: 301 (1969).

8. Stggandd-Anderson, O.; Engel, K.; Jorgensen, K.; \& Astrup, P. A Micro Method for Determination of $\mathrm{pH}$, Carbon Dioxide Tension, Base Excess and Standard Bicarbonate in Capillary Blood. Scandinav. J. Clin. \& Lab. Invest., 12: 172 (1960).

9. Nelson, N. M.; Prod'hom, L. S.; Cherry, R. B.; \& Smith, C. A. A Further Extension of the In Vivo Oxygen-Dissociation Curve for the Blood of the Newborn Infant. J. Clin. Invest., 43: 606 (1964).

10. Apgar, V. A Proposal for a New Method of Evaluation of the Newborn Infant. Anesth. \& Analg., 32: 260 (1953).

11. James, L. S.; Weisbrot, I. M.; Prince, C. E.; Holaday, D. A.; \& Apgar, V. The AcidBase Status of Human Infants in Relation to Birth Asphyxia and the Onset of Respiration. J. Pediat., 52:379 (1958).

12. Hill, A. B. Principles of Medical Statistics. New York. Oxford University Press (1961). Chapter 15, The Coefficient of Correlation.

13. Baraka, A. Correlation Between Maternal and Foetal $\mathrm{PO}_{2}$ and $\mathrm{PCO}_{2}$ During Caesarean Section. Brit. J. Anaesth., 42: 434 (1970).

14. Rorke, M. J.; DaveY, D. A.; \& Du Tort, H. J. Foetal Oxygenation During Caesarean Section. Anaesthesia, 23:585 (1968).

15. Apgar, V., \& James, L. S. The First Sixty Seconds of Life. Chapter 9, in Abramson, H. Resuscitation of the Newborn Infant. Ed. 2. St. Louis, C. V. Mosby Company (1966).

16. Dawes, G. S. Foetal and Neonatal Physiology. Chicago, Year Book Medical Publishers (1968). Chapter 15, Oxygen Consumption and Temperature Regulation in the Newborn.

17. Ibid. Chapter 3, Oxygen Transfer Across the Placenta.

18. Crawford, J. S. Anaesthesia for Caesarean Section: A Proposal for Evaluation, with Analysis of a Method. Brit. J. Anaesth., 34: 179 (1962). 